\title{
Inside the Plants: Bacterial Endophytes and their Natural Products
}

\author{
Pramod Kumar Pandey ${ }^{1,2^{*}}$, Siddhartha Singh ${ }^{2}$, Mayanglambam Chandrakumar Singh ${ }^{2}$, \\ Amit Kumar Singh ${ }^{2}$, Pratibha Pandey ${ }^{3}$, Ajai Kumar Pandey ${ }^{2}$, Mahesh Pathak ${ }^{4}$, \\ Mukul Kumar ${ }^{2}$, Ramesh Chandra Shakywar ${ }^{2}$ and Raghubir Kumar Patidar ${ }^{2}$ \\ ${ }^{1}$ Centre for Biotechnology and Bioinformatics, Dibrugarh University, \\ Dibrugarh-786004, Assam, India \\ ${ }^{2}$ College of Horticulture and Forestry, Central Agricultural University, Pasighat-791102, \\ Arunachal Pradesh, India \\ ${ }^{3}$ Department of Biological Science, Faculty of Science and Environment, Mahatma Gandhi \\ Chitrakoot Gramodaya Vishwavidyalaya, Chitrakoot, Satna- 485334, Madhya Pradesh, India \\ ${ }^{4}$ Krishi Vigyan Kendra, College of Horticulture and Forestry, Central Agricultural University, \\ Pasighat-791102, Arunachal Pradesh, India \\ *Corresponding author
}

\section{A B S T R A C T}

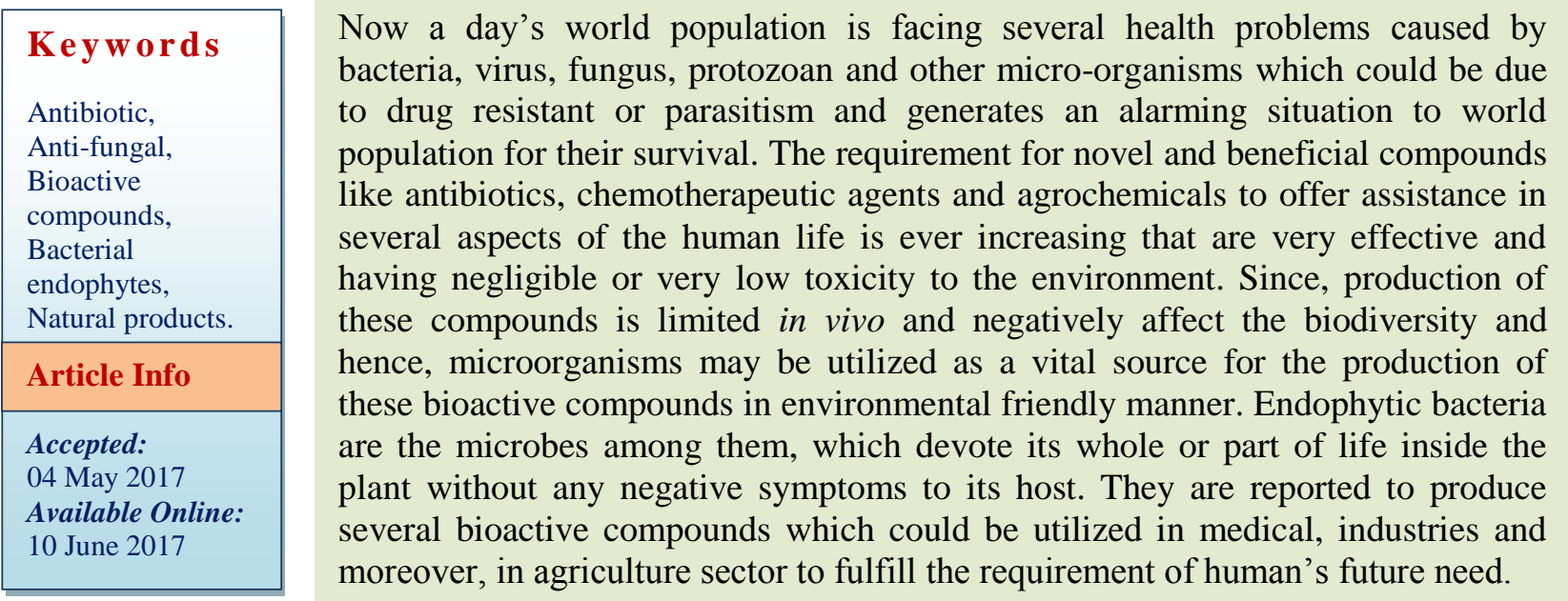

\section{Introduction}

Almost all plants of the world are a potential inhabitants of indigenous microbes principally recognized as endophytic microbes which can reside inside their tissue without giving any visible external symptoms which is responsible for nutrient assimilation and their processing, induction of defense system and synthesis of secondary metabolites (Pandey et al., 2017). They may be actinomycetes, bacteria or fungi (Pandey et $a l ., 2016 b$ ). It is found that during the course of evolution certain microbes were able to enter the plant tissues, either with the help of synthesis of cell wall hydrolyzing enzymes 
like pectinease, cellulase or by developing some other mechanisms and reside inside the plant tissue and co-evolved. During coevolution, they may be adapted towards the interior environment of the host plant involving the mechanisms of cross talk between the endophytes and the host plants (Pathak, 2011; Pandey et al., 2016c). They colonize internal tissues of the plants either as obligate or in facultative manner without showing any immediate negative or external symptoms and reported to display the beneficial effects, put forward opportunities for discovering products and processes with potential applications in agriculture, medicine and biotechnology (Pandey et al., 2012, 2014, 2015, 2016a, 2017). Bacterial endophytes stimulate plant growth, directly or indirectly thereby increasing their yield and several parameters utilized by living things for their life prospects (Gray and Smith, 2005; Pandey et al., 2012, 2015, 2016). They offer an extensive range of benefits to the host plant against biotic and abiotic stresses (Hurek and Hurek, 2011). In return, the bacterial endophytes may be benefited by the various secondary metabolites and the growth regulators produced by the host plants (Schulz and Boyle, 2006). Endophytic bacteria were reported to produce novel bioactive compounds which were not previously found to be reported naturally in plants such as insecticides, antimicrobials, etc., (Ryan et al., 2008).

Endophytic bacteria associated with medicinal plants hold a good opportunity to produce antibiotic to ameliorate negative effects of pathogenic fungi, bacteria and virus. There is a strong requirement for the invention of new metabolites and to explore alternative pathway by employing endophytic bacteria which are effective and cause less or no damage to the environment and replace the artificial chemicals and pesticides.

\section{Natural products from bacterial endophytes}

Now a day's world population is facing several health problems caused by bacteria, virus, fungus, protozoan and other microorganisms which could be due to drug resistant or parasitism and generates an alarming situation to world population for their survival. Research based on the invention of medicinal and novel biactive compounds from endophytic bacteria is a promising task. There is a strong need for production of new drugs, especially antibiotics, anticancer agents, immunomodulatory compounds, bioactive compound that is effective, but cause less or no damage to the milieu and replace the synthetic fertilizers and pesticides with more ecofriendly bio-fertilizers and bio-control agents. Bacterial endophytes may be used for the production of new pharmaceutical agents and agrochemical compounds. There is tremendous scope for the isolation of novel bioactive medicinal compounds from endophytic bacteria. Several classes of natural products such as antibacterial, antifungal antibiotics, antiviral, volatile insecticides, herbicidal, and plant growth promoting, plant protective agents have been reported to be produced by bacterial endophytes (Table 1). However, there are also some reports of production of harmful substances to predators of the host plants (Bacon et al., 1977; Clay et al., 1989; Suto et al., 2002). Leucinostatin A production from Acremonium sp. isolated from Taxus baccata is found to be active against breast cancer (Strobel et al., 1997). Pseudomonas viridiflava is a fluorescent bacteria located within the tissues associated with the leaves of many grass species produces ecomycins which represent a family of novel lipopeptides. The structure of these lipopeptides involves common amino acids such as alanine, serine, threonine, glycine and some unusual amino acids like homoserine 
and $\beta$-hydroxyaspartic acid, which are active against pathogenic fungi such as Cryptococcus neoformans and C. albicans. Pseudomycins, another group of antifungal compounds is also produced by plantassociated pseudomonads (Harrison et al., 1991; Miller et al., 1998; Strobel and Daisy, 2003).

An ample range of biologically active compounds has been isolated from bacterial endophyte but they still remain a relatively untapped source of novel natural products. Most researches focus on fungal-based antimicrobial bioactive products. A plentiful low-molecular- weight compounds which are active at low concentrations against a range of animal and plant pathogen have been isolated from bacterial endophytes. However, comprehensive screenings for antiviral compounds from bacterial endophytes have yet to be reported. Many endophytes are members of common soil bacterial genera, such as Pseudomonas and Burkholderia
(Lodewyckx et al., 2002) and are well known for their secondary metabolites that include antibiotics, anticancer compounds, insecticidal, antifungal, antiviral, and immunosuppressant agents. Bioplastics are biomaterials that are receiving increasing commercial interest. Genomic analysis indicates that many species of bacteria have the potential to produce bioplastics (Kalia et al., 2003). Bioplastic poly-3-hydroxybutyrate (PHB) is polyester produced by Bacillus megaterium (Lemoigne, 1926). The most widely produced microbial bioplastics are poly-3-hydroxyalkanoate (PHA) and poly-3hydroxybutyrate (PHB). Herbaspirillum seropedicae, reported to colonize a variety of plants and utilize a diverse range of carbon sources, accumulates significant levels of poly-3-hydroxybutyrate (PHB). Bacteria and higher plants having accumulation ability of PHAs may also help to produce novel heteropolymers for a range of applications (Aldor and Keasling, 2003; Catalan et al., 2007).

Table.1 Bioactive compounds from bacterial endophytes

\begin{tabular}{|c|c|c|c|}
\hline Bacterial endophyte & Source & $\begin{array}{l}\text { Bioactive anti-fungal } \\
\text { compound/ Function }\end{array}$ & Reference \\
\hline Paenibacillus polymyxa & $\begin{array}{l}\text { Wheat, Lodge pine, } \\
\text { Green beans, Arabidopsis } \\
\text { thaliana and Canola }\end{array}$ & $\begin{array}{l}\text { Fusaricidin A-D } \\
\text { (Antifungal) }\end{array}$ & $\begin{array}{l}\text { Beck et al., 2003; Li } \\
\text { et al., } 2007\end{array}$ \\
\hline Serratia marcescens & Rhyncholacis penicillata & Oocydin A (Antifungal) & Strobel et al., 2004 \\
\hline Bacillus sp. & Paddy & Antifungal activity & Wang et al., 2009 \\
\hline Bacillus subtilis & Wheat & Antifungal protein E2 & Liu et al., 2010 \\
\hline Pseudomonas syringae & ------ & Pseudomycins & Harrison et al., 1991 \\
\hline Bacillus pumilus MAIIIM4A & Cassava & Antifungal metabolites & De Melo et al., 2009 \\
\hline $\begin{array}{l}\text { Burkholderia brasiliensis } \\
\text { M130 }\end{array}$ & Rice root & $\begin{array}{l}\text { EPS A and EPS B } \\
\text { (Plant- microbe } \\
\text { interaction) }\end{array}$ & $\begin{array}{l}\text { Leigh and Coplin, } \\
1992\end{array}$ \\
\hline Bacillus subtilis BS-2 & Capsicum leaves & $\begin{array}{l}\text { Antifungal protein } \\
\text { (thermostable and UV- } \\
\text { tolerant) }\end{array}$ & He et al., 2003 \\
\hline B. cereus & Mustard & $\begin{array}{l}\text { Chitinase } \\
\text { (Antifungal) }\end{array}$ & Pleban et al., 2003 \\
\hline Pseudomonas viridiflava & Grass species & Ecomycins & Miller et al., 1998 \\
\hline
\end{tabular}


Methylobacterium extorquens and Pseudomanas synxantha

Pseudomonads

P. viridiflava strain EB274 and EB227

Streptomyces NRRL 30562

Streptomyces NRRL30566

Streptomyces sp. strain

GT2002/1503

$\begin{array}{ll}\begin{array}{l}\text { Streptosporangium } \\ \text { oxazolinicum K07-0450 }\end{array} & - \\ \begin{array}{l}\text { Bacillus licheniformis and } \\ \text { Bacillus pumilus }\end{array} & \begin{array}{l}\text { Balloon flower } \\ \text { (Platycodon } \\ \text { grandiflorum) }\end{array} \\ \text { Bacillus mojavensis } & - \\ \text { Paenibacillussp. IIRAC-30 } & \begin{array}{l}\text { cassava (Manihotes } \\ \text { culenta) }\end{array} \\ \text { Bacillus amyloliquefaciens } & \begin{array}{l}\text { Scutellaria baicalensis } \\ \text { Georgi }\end{array}\end{array}$

Streptomyces sp.

Streptomyces NRRL 30562

Shewanella sp. and Pseudomonas sp.
Scots pine (Pinus sylvestris $\mathrm{L}$.)

Snake vine [Kennedia nigriscans]

Grevillea tree [Grevillea pteridifolia]

Bruguiera gymnorrhiza

.

Monstera sp.

Snakevine (Kennedia nigriscans)

Ageratum conyzoides
(Antifungal

lipopeptides)

Adenine derivatives

(Precursors in cytokinin Pirttila et al., 2004 biosynthesis)

\section{2,4-}

diacetylphloroglucinol

(DAPG)

Ramesh et al., 2008

(Antimicrobial)

Ecomycins B and C (antifungal lipopeptides)

Harrison et al., 1991 Munumbicins A, B, C and D

Castillo et al., 2002

(anti-microbial)

Kakadumycin A (antibiotics)

Castillo et al., 2003

Xiamycin-A (anti-HIV activity)

Ding et al., 2010 Spoxazomicins A-C (antitrypanosomal alkaloids)

Inahashi et al., 2011

Antifungal compound $\quad$ Asraful et al., 2010

Leu $^{7}$ - surfactin

(Anti-fungal)

Snook et al., 2009

C15- lipopeptide

(Anti-fungal)

Canova et al., 2010

fengycin homologues

and surfactin

homologues

Sun et al., 2006

(anti-microbial)

Coronamycin

(antifungal and

antimalarial)

munumbicins E-4 and E-

5

(antifungal and

Castillo et al., 2006

Ezra et al., 2004

antimalarial)

2-amino-3-

quinolinecarbonitrile and boric acid

Fitriani et al., 2015 (Antibacterial)

First report of indolesesquiterpenes (xiamycin $\mathrm{B}$, indosespene, and sespenine together with the known xiamycin A) is from the culture broth of Streptomyces sp. HKI0595, a 
bacterial endophyte. It is used as a biocontrol agent and has been identified for strong antimicrobial activities against different pathogenic bacteria such as Staphylococcus aureus and Enterococcus faecalis which are resistant towards methicillin and vancomycin respectively (Ding et al., 2011). Ammonia, butyrolactones, 2,4-diacetyl phloroglucinol, kanosamine, oligomycin A, oomycin A, phenazine-1-carboxylic acid, pyoluteorin, pyrrolnitrin, viscosinamide, xanthobaccin and zwittermycin A are the antibiotics produced by antagonistic bacteria (Whipps et al., 2001). They produce hydrolytic enzymes that cause cell wall lysis, which can be used to control fungal pathogens (Backman and Sikora, 2008) and biosurfactants as antimicrobial compounds (Nielson et al., 1999; Nielson et al., 2000; Bais et al., 2004). Pseudomonas fluorescens produces cyclic lipopeptides surfactants, such as viscosinamide (Nielson et al., 1999), and tensin (Nielson et al., 2000) with antifungal activity against Rhizoctonia solani and Pythiu multimum (Nielson et al., 2000). Lanna-Filho et al., (2013) partially characterized Protein fractions 42 and 75 from the Bacillus amyloliquefaciens and Bacillus pumilus. These protein fractions 42 and 75 were acting as elicitor in induced resistance against pathogen Xanthomonas vesicatoria in tomato plant and reduce the bacterial spot up to the extent of 63.5 and $56.6 \%$ respectively as compared with control plant along with an increase in the peroxidase (POX) and polyphenol oxidase (PPO) enzyme activities. These protein fractions were appearing as a single band of molecular mass of 28 and $43 \mathrm{kDa}$, respectively on SDS-PAGE silver staining. Endophytic bacterial isolates from healthy peanut plants were evaluated against the peanut bacterial wilt (BW) caused by Ralstonia solanacearum. Isolate BZ6-1 characterized as Bacillus amyloliquefaciens on the basis of morphology, biochemical and $16 \mathrm{~S}$ rRNA analysis were identified as to the highest antimicrobial activity. The main antimicrobial compound surfactin and fengycin A homologs were examined by high performance liquid chromatography electrospray ionization tandem mass spectrometry (Wang and Liang, 2014). Endophytic bacteria Lactobacillus sp. isolated from the leaf tissues of Adhathoda beddomei were investigated for the presence of bioactive compound. Bioactive compound was extracted by solvent- solvent methods. Qualitative tests of the extracts showed the presence of carbohydrates, tannins, saponins, alkaloids, glycosides, proteins, amino acids and saponins while presence of phenolic compounds were reported to be $0.67 \mathrm{mg} / \mathrm{ml}$ (Swarnalatha et al., 2015).

\section{Acknowledgement}

We are highly grateful to Department of Biotechnology, Government of India for providing research grant under the project "Institutional Biotechnology Hub" at College of Horticulture and Forestry, Central Agricultural University, Pasighat-791102, Arunachal Pradesh.

\section{References}

Aldor, L.S. and Keasling, J.D. 2003. Process design for microbial plastic factories: metabolic engineering of polyhydroxyal kanoates. CurrOpinBiotechnol, 14; 475-483.

Asraful Islam, S., Math, R., Kim, J., Yun, M., Cho, J., Kim, E., Lee, Y., Yun, H. 2010.Effect of plant age on endophytic bacterial diversity of balloon flower (Platycodon grandiflorum) root and their antimicrobial activities. Curr. Microbiol, 61; 346-356.

Backman, P.A. and Sikora, R.A. 2008. Endophytes: an emerging tool for biological control. BiolContr, 46; 1-3.

Bacon, C.W., Porter, J.K., Robbins, J.D. and Luttrell, E.S. 1977. Epichloë typhina 
from toxic tall fescue grasses. ADDI EnvMicrob, 34; 576-581.

Bais, H.P., Fall, R. and Vivanco, J.M. 2004. Biocontrol of Bacillus subtilis against infection of Arabidopsis roots by Pseudomonas syringae is facilitated by biofilm formation and surfactin production. Plant Physiol, 134; 307319.

Beck, H.C., Hansen, A.M. and Lauritsen, F.R. 2003. Novel pyrazine metabolites found in polymyxin biosynthesis by Paenibacillus polymyxa. FEMS MicrobiolLett, 220; 67-73.

Canova, S., Petta, T., Reyes, L., Zucchi, T., Moraes, L., Melo, I. 2010.Characterization of lipopeptides from Paenibacillus sp. (IIRAC30) suppressing Rhizoctonia solani. W J Microbiol Biotech, 26; 2241-2247.

Castillo, U., Harper, J.K., Strobel, G.A., Sears, J., Alesi, K., Ford, E., Lin, J., Hunter, M., Maranta, M., Ge, H., Yaver, D., Jensen, J.B., Porter, H., Robison, R., Millar, D., Hess, W.M., Condron, M., Teplow, D. 2003. Kakadumycins, novel antibiotics from Streptomyces sp. NRRL 30566, an endophyte of Grevillea pteridifolia. FEMS MicrobiolLett, 224; 183-90.

Castillo, U., Strobel, G., Mullenberg, K., Condron, M., Teplow, D., Folgiano, V., Gallo, M., Ferracane, R., Mannina, L., Viel, S., Codde, M., Robison, R., Porter, H., Jensen, J. 2006. Munumbicins E-4 and E-5: novel broad-spectrum antibiotics from Streptomyces NRRL3052. FEMS MicrobiolLett, 255; 296-300.

Castillo, U.F., Strobel, G.A., Ford, E.J., Hess, W.M., Porter, H., Jensen, J.B., Albert, H., Robison, R., Condron, M.A., Teplow, D.B., Stevens, D., Yaver, D. 2002. Munumbicins, wide-spectrum antibiotics produced by Streptomyces
NRRL 30562, endophytic on Kennedia nigriscans. Microbiology,148; 2675-85.

Catalan, A.I., Ferreira, F., Gill, P.R. and Batista, S. 2007.Production of polyhydroxy alkanoates by Herbaspirillum seropedicae grown with different sole carbon sources and on lactose when engineered to express the lacZlacY genes. Enzyme Microbial Technol, 40; 1352-1367.

Clay, K. 1989. Clavicipitaceous endophytes of grasses: their potential as biocontrol agents. Mycol Res, 92; 1.

deMelo, F.M.P., Fiore, M.F., de Moraes, L.A.B., Silva-Stenico, M.E., Scramin, S., de Araújo, Teixeira, M., de Melo, I.S. 2009. Antifungal compound produced by the cassava endophyte Bacillus pumilus MAIIIM4A. SciAgric (Piracicaba, Braz.), 66(5); 583-592.

Ding, L.,Maier, A.,Fiebig, H.-H.,Lin, W.-H. andHertweck, C. 2011. A family of multicyclic indolosesquiterpenes from a bacterial endophyte.Org BiomolChem, 9; 4029 - 4031 .

Ding, L., Münch, J., Goerls, H., Maier, A., Fiebig, H.H., Lin, W.H., Hertweck, C. 2010. Xiamycin, a pentacyclic indolosesquiterpene with selective antiHIV activity from a bacterial mangrove endophyte. Bioorg Med ChemLett, 20; 6685-7.

Ezra, D., Castillo, U., Strobel, G., Hess, W., Porter, H., Jensen, J., Condron, M. 2004. Coronamycins, peptide antibiotics produced by a verticillate Streptomyces sp. (MSU-2110) endophytic on Monstera sp. Microbiol, 150;785-793.

Fitriani, A., Ihsan, F., Hamdiyati, Y. and Maemunah. 2015. Antibacteria activity of Shewanella and Pseudomonas as endophytic bacteria from the root of Ageratum conyzoides L. Asian J ApplSci, 03(03); 415-420.

Gray, E.J. and Smith, D.L. 2005. Intracellular and extracellular PGPR commonalities 
and distinctions in the plant-bacterium signalling processes. Soil BiolBiochem, 37; 395-412.

Harrison, L.H., Teplow, D.B., Rinaldi, M., Strobel, G. 1991. Pseudomycins, a family of novel peptides from Pseudomonas syringae possessing broad-spectrum antifungal activity. J Gen Microbiol, 137; 2857-65.

He, H., Cai, X., Guan, X., Hu, F. and Xie, L. 2003. Acta Phytopathol Sin, 33; 373 (in Chinese).

Hurek, B.R. and Hurek, T. 2011. Living inside plants: bacterial endophytes.CurrOpin Plant Biol, 14; 435-443.

Inahashi, Y., Iwatsuki, M., Ishiyama, A., Namatame, M., Nishihara, T.A., Matsumoto, A., Hirose, T., Sunazuka, T., Yamada, H., Otoguro, K., et al. 2011.Spoxazomicins A-C, novel antitrypanosomal alkaloids produced by an endophytic actinomycete, Streptosporangium oxazolinicum K070450T. J Antibiot, 64; 303-307.

Kalia, V.C., Chauhan, A. and Bhattacharyya, G. 2003. Genomic databases yield novel bioplastic producers. Nat Biotechnol, $21 ; 845-846$.

Lanna-Filho, R., Souza, R.M., Magalhães, M.M., Villela, L., Zanotto, E., RibeiroJúnior, P.M. and Resende, M.L.V. 2013. Induced defense responses in tomato against bacterial spot by proteins synthesized by endophytic bacteria. Tropical Plant Pathology, 38(4); 295302.

Leigh, J.A. and Coplin, D.L. 1992. Exopolysaccharides in plant-bacterial interactions.Annu Rev Microbiol, 46; 307-46.

Lemoigne, M. 1926. Produits de d'eshydratationet de polym'erisation de l'acid $\quad \beta$-oxybutyrique. Bull SocChemBiol, 8; 770-782.
Li, J., Beatty, P.K., Shah, S. and Jensen, S.E. 2007.Use of PCR-targeted mutagenesis to disrupt production of Fusaricidintype antifungal antibiotics in Paenibacillus polymyxa.ApplEnvMicrobiol, 73, 3480 $-3489$.

Liu, B., Huang, L., Buchenauer, H., Kang, Z. 2010. Isolation and partial characterization of an antifungal protein from the endophytic Bacillus subtilis strain EDR4. Pesticide Biochemistry and Physiology, 98; 305-311.

Lodewyckx, C., Vangronsveld, J., Porteous, F., Moore, E.R.B., Taghavi, S., Mezgeay, M. and Van der Lelie, D. 2002. Endophytic bacteria and their potential applications. Crit Rev Plant Sci, 21; 583-606.

Miller, C.M., Miller, R.V., Garton-Kenny, D., Redgrave, B., Sears, J., Condron, M.M., et al. 1998. Ecomycins, unique antimycotics from Pseudomonas viridiflava. J ApplMicrobiol, 84; 93744.

Nielson, T.H., Christopheresen, C., Anthoni, U. and Sorensen, J. 1999. Viscosinamide, a new cyclic depsipeptide with surfactant and antifungal properties produced by Pseudomonas fluorescens DR54. J ApplMicrobiol, 87; 80-90.

Nielson, T.H., Tharne, C., Christophersen, C., Anthoni, U. and Sorensen, J. 2000. Structure, production characteristics and fungal antagonism of tensin-a new antifungal cyclic lipopeptide from Pseudomonas fluorescens strain 96.578.J ApplMicrobiol, 89; 992-1001.

Pandey, P.K., Samanta, R., and Yadav, R.N.S. 2015.Plant Beneficial Endophytic Bacteria from the Ethnomedicinal Mussaenda roxburghii (Akshap) of Eastern Himalayan Province, India. Advances in Biology, Article ID 580510, 8. doi:10.1155/2015/580510. 
Pandey, P.K., Samanta, R., and Yadav, R.N.S. 2016a. Functional attributes of Solanum kurzii associated bacterial endophytes for plant growth promotion. Asian Jr of Microbiol Biotech EnvSc, 18(2); 145158.

Pandey, P.K.,Singh, M.Ck., Singh, A.K., Singh, S., Pandey, A.K., Pathak, M., Kumar, M., Shakywar, R.C., Patidar, R.K. and Devi, M.B. 2016b. Arsenal of endophytic actinobacterial microbes. Int J CurrMicrobiol App Sci, 5(3); 62-66.

Pandey, P.K., Singh, S., Singh, A.K., Samanta, R., Yadav, R.N.S. and Singh, M.Ck. 2016c. Inside the plant: Bacterial endophytes and abiotic stress alleviation. J Appl Natural Sci, 8(4); 1899-1904.

Pandey, P.K., Singh, M.Ck., Singh, S., Singh, A.K., Kumar, M., Pathak, M., Shakywar, R.C. and Pandey, A.K. 2017. Inside the Plants: Endophytic bacteria and their functional attributes for plant growth promotion. Int $\mathrm{J}$ CurrMicrobiol App Sci, 6(2); 11-21.

Pandey, P.K., Singh, S., Yadav, R.N.S., Singh, A.K., Singh, M.Ck. 2014. Fungal Endophytes: Promising tools for pharmaceutical science. Int J Pharm Sci Rev Res, 25(2); 128-138.

Pandey, P.K., Yadav, S.K., Singh, A., Sarma, B.K., Mishra, A. and Singh, H.B. 2012.Cross-Species Alleviation of Biotic and Abiotic Stresses by the Endophyte Pseudomonas aeruginosa PW09. J Phytopathology, 160; 532-539.

Pathak, K.V. 2011. Purification and characterization of antifungal compounds produced by banyan endophytic Bacilli. PhD Thesis, Sardar Patel University, VallabhVidyanagar, Gujarat, India.

Pirttila, A.M., Joensuu, P., Pospiech, H., Jalonen, J. and Hohtola, A. 2004.Bud endophytes of Scots pine produce adenine derivatives and other compounds that affect morphology and mitigate browning of callus cultures. Physiol Plant, 121; 305-312.

Pleban, S., Chernin, L. and Chet, I. 1997. Chitinolytic activity of an endophytic strain of Bacillus cereus. LettApplMicrobiol, 25; 284-8.

Ramesh, R., Joshi, A. and Ghanekar, M.P. 2008. Pseudomonads: Major antagonistic endophytic bacteria to suppress bacterial wilt pathogen, Ralstonia solanacearum in the eggplant (Solanum melongena L.). World J Microbiol and Biotech, 25; $47-55$.

Ryan, R.P., Germaine, K., Franks, A., Ryan, D.J. and Dowling, D.N. 2008. Bacterial endophytes: recent developments and applications. FEMS MicrobiolLett, 278; $1-9$.

Schulz, B. and Boyle, C. 2006. What are endophytes? In: Schulz, B.J.E., Boyle, C.J.C., Sieber, T.N. (eds) Microbial Root Endophytes. Berlin, SpringerVerlag, 1-13.

Snook, M., Mitchell, T., Hinton, D., Bacon, C. 2009.Isolation and characterization of leu7-surfactin from the endophytic bacterium Bacillus mojavensis RRC 101, a biocontrol agent for Fusarium verticillioides. J Agri Food Chem, 57; 4287-4292.

Strobel, G. and Daisy, B. 2003. Bioprospecting for microbial endophytes and their natural products. MicrobiolMolBiol Rev, 67(4); 491-502.

Strobel, G., Daisy, B., Castillo, U. and Harper, J. 2004. Natural products from endophytic microorganisms. J Nat Prod, $67 ; 257-268$.

Strobel, G.A., Torczynski, R. and Bollon, A. 1997. Acremonium sp. a leucinostatin A producing endophyte of European yew (Taxus baccatu). Plant Sci, 128; 97108.

Sun, L., Lu, Z., Bie, X., Lu, F., Yang, S. 2006.Isolation and characterization of a 
co-producer of fengycins and surfactins, endophytic Bacillus amyloliquefaciens ES-2, from Scutellaria baicalensis Georgi. W J Microbiol Biotech, 22; 1259-1266.

Suto, M., Takebayashi, M., Saito, K., Tanaka, M., Yokota, A. and Tomita, F. 2002.Endophytes as Producers of Xylanase. Journal of bioscience and bioengineering, 93(1); 88-90.

Swarnalatha, Y., Saha, B. and Lokeswara Choudary, Y.2015. Bioactive compound analysis and antioxidant activity of endophytic bacterial extract from Adhathoda beddomei. Asian J Pharm Clin Res, 8(1); 70-72.
Wang, H., Wen, K., Zhao, X., Wang, X., et al., 2009. The inhibitory activity of endophytic Bacillus sp. strain CHM1 against plant Pathogenic fungi and its plant growth-promoting effect. Crop Prot, 28; $634-639$.

Wang, X. and Liang, G. 2014. Control Efficacy of an Endophytic Bacillus amyloliquefaciens Strain BZ6-1 against Peanut Bacterial Wilt, Ralstonia solanacearum. BioMed Research International, 465435; 1-11.

Whipps, J. 2001. Microbial interactions and biocontrol in the rhizosphere. J Exp Bot, $52 ; 487-511$.

\section{How to cite this article:}

Pramod Kumar Pandey, Siddhartha Singh, Mayanglambam Chandrakumar Singh, Amit Kumar Singh, Pratibha Pandey, Ajai Kumar Pandey, Mahesh Pathak, Mukul Kumar, Ramesh Chandra Shakywar and Raghubir Kumar Patidar. 2017. Inside the Plants: Bacterial Endophytes and their Natural Products. Int.J.Curr.Microbiol.App.Sci. 6(6): 33-41. doi: https://doi.org/10.20546/ijcmas.2017.606.003 